\title{
Juridische zaken
}

In deze rubriek bespreekt Joost Quant, advocaat in Amsterdam, actuele juridische aangelegenheden van belang voor de kinderopvang.

\section{Corona; waar staan we?}

\author{
De impact van het coronavirus is enorm. Vooral voor de kinderopvang waar de factor \\ arbeid een belangrijke factor is; ook in financieel opzicht. Welke juridische vraagstukken \\ spelen nu vooral als het gaat om arbeidsrecht?
}

De vraag die regelmatig wordt gesteld is of werknemers thuis kunnen blijven uit angst besmet te raken. Laat ik vooropstellen dat een werknemer die zich niet goed voelt (vanwege corona-gerelateerde klachten) vanzelfsprekend thuis dient te blijven. Sterker: die werknemer heeft de plicht om thuis te blijven. Van deze werknemer mag ook worden verwacht dat die zich laat testen. De werkgever mag dat in mijn optiek ook actief verzoeken. Als blijkt dat de test negatief is, en de verschijnselen op zich geen reden zouden zijn om thuis te blijven, dan meen ik dat de werknemer ook naar het werk dient te komen.

\section{Niet willen werken}

Maar wat nou als een werknemer geen corona-gerelateerde klachten heeft en niet wil komen werken uit angst besmet te raken? Van belang is dat je als werkgever de plicht hebt om te zorgen voor een veilige werkomgeving. Als je kunt aantonen dat dat het geval is, en de nodige maatregelen zijn getroffen, dan zou je iemand naar mijn idee kunnen verplichten om te komen. Komt iemand niet, dan geldt het arbeidsrechtelijke beginsel: 'geen arbeid, geen loon'. Maar voordat je zover gaat, moet wel eerst gekeken worden naar alternatieven. Bijvoorbeeld of het mogelijk is om thuis te werken. Dat zal in de kinderopvang veelal niet het geval zijn. Ook zul je de belangen tegen elkaar moeten afwegen; waarom wil iemand niet komen en is dat een goede reden? Bijvoorbeeld omdat er een verhoogd gezondheidsrisico is. Is dat risico er niet, dan kan het loon worden stopgezet. Een mogelijk alternatief is nog dat wordt afgesproken dat er verlof wordt opgenomen.

\section{Vakantiedagen}

Veel geboekte of geplande vakanties zijn niet doorgegaan. Wat gebeurt er dan met de wettelijke vakantiedagen? De wettelijke vakantiedagen (20 op fulltime basis) van 2019 vervallen dan per 1 juli 2020. Het is van belang om er bij werknemers op aan te dringen om wel vakantiedagen op te nemen in perioden dat het rustig is. Feit is dat de vakantiedagen volgens de wet in overleg en overeenkomstig de wensen van de werknemer worden vastgesteld. Desondanks meen ik dat, zeker in deze tijd, van werknemers verlangd kan worden dat zij in de gebruikelijke vakantietijd (waarin het rustig is in de kinderopvang) ook daadwerkelijk vakantie opnemen. Een maatregel die wat verdergaat, is om de werknemers te vragen (of te verplichten) de bovenwettelijke vakantiedagen (die bovenop de wettelijke vakantiedagen komen) in te leveren. Vooral in het geval waarin werknemers langdurig thuis hebben gezeten is dat het overwegen waard. Bedenk wel dat daar geen wettelijke grond voor is en het arbeidsrechtelijk twijfelachtig is. Maar dit is een uitzonderlijke tijd. En in tijden waarin iets gebeurt dat onmogelijk werd geacht, wordt het onmogelijke wellicht mogelijk. <

JOOST QUANT IS ADVOCAAT IN AMSTERDAM EN TEVENS LID VAN DE RAAD VAN TOEZICHT VAN DE SKBNM. [JOOST.QUANT@GALATEA.LAW] 